\title{
Research on Strategies for the Development of National Orchid Culture Industry Based on PEST Analysis*
}

\author{
Mo Chen \\ Zhejiang Ocean University \\ Zhoushan, China 316022
}

\begin{abstract}
The 13th Five-Year Plan put forward to expand new space for development. The new space for development can cultivate new impetuses for development, and in turn the new impetuses for development can expand new space for development. It can support the optimization and upgrading of traditional industries. It is one way to optimize and upgrade the traditional industry by the development of the national orchid culture industry. In addition, the national orchid culture of Zhoushan, an island city of Zhejiang, is rich, and the orchid industry needs to be developed. It quite meets propose to expand new space for development. According to the development status of national and foreign culture industry, takes the New District of coastal Zhoushan Islands as an example to discuss the development obstacles of our national orchid culture industry. Uses the analysis method of PEST, and by analyzing political factors, economic factors, socialcultural factors and technological factors, the author deeply analyzed the development strategies of our orchid culture industry. Strengthens the spread of our national culture, creates our national orchid culture brands, dig the cultural communication value of our national orchid to make sales not only limited to the simple exchange of equivalence, help consumers explore the cultural value contained in it further, forming a far-reaching impact.
\end{abstract}

Keywords—national orchid culture industry; development status; PEST analysis

\section{INTRODUCTION}

Advice of the Central Committee of the Communist Party of China on the Formulation of the 13th Five-Year Plan for National Economic and Social Development put forward to expand new space for development. The new space for development can cultivate new impetuses for development, and in turn the new impetuses for development can expand new space for development. It can support the development of new emerging industries, including energy conservation and environmental protection, biotechnology and information technology, and support the optimization and upgrading of traditional industries and popularize new incubation mode and encourage people to develop spaces for

*Fund project: Research on National Orchid Cultural System Based on Traditional Culture, a department-level cultural scientific research project of Zhejiang Provincial Culture Department in 2017 (No.: zw2017035). crowd-creating, crowd-sourcing, crowd-supporting and crowd-investing. The period of the 13th Five-Year Plan is a key period for the construction of a new-typed marine power. It takes to ensure the national maritime security and economic development as basic goal. With a national and global vision, it suggested to make full use of world ocean space to develop world ocean resources and protect the marine ecological environment, optimize and develop the coastal zone and the adjacent sea area, strengthen island protection and ecological construction, and mainly develop the continental shelf and the exclusive economic zones, thus expand blue economic space for national development. It is good way to update the traditional industry by developing our national orchid culture industry. In addition, the national orchid culture of Zhoushan, an island city of Zhejiang, is rich, and the orchid industry needs to be developed. It quite meets propose to expand new space for development.

\section{THE DEVElOPMENT STATUS OF THE WORLD ORCHID CULTURE INDUSTRY}

\section{A. Foreign Orchid Culture Industry}

Two orchids were carved on an ancient tablet of 1930s, which is considered to be the earliest orchid record in the West. The ancient Rome culture is the source of western culture. Ancient Rome once traversed the three continents of Asia, Africa and Europe, dominated the Mediterranean, where many ethnic cultures collided and made great contributions to world culture. The origin and growth of plant medicine and science on the coastal land finally achieved today's flower culture. As a part of European flower culture, orchids have a great influence on the orchid culture all over the world.

Not only the West has orchid culture, and the Southeast Asia also has this culture. Thailand, a coastal country, is a country with unique natural environment and excellent production conditions for the planting of orchid. People living in Thailand love orchids. Walking along the coastal land, you can see many kinds of orchids in the garden. A gust of wind blows, fragrance strikes nose. In large, medium and small-sized cities, there are orchids in both residential areas and tourism areas. In Japan, the orchid culture has a 
deep historical origin. It can be said orchid culture is all over the world.

\section{B. Chinese Orchid Culture Industry}

Today's Chinese orchid, called national orchid for short, was called "orchid flower" in ancient times. That is what the Japanese call "oriental orchid" and what the Westerners call "East Asian orchid". As early as 600 B.C. to 1000 B.C., Book of Songs recorded orchid and named it "Chan" [1]. According to National Briefing, it says: "in a broad sense, Chinese orchid should include all orchids grown in China." Generally speaking, Chinese orchids usually refer to 7 main categories, including goeringii, sword-leaved orchid, faberi, cymbidium kanran, cymbidium longibracteatum and lotuspetal-shaped orchid [2].

China's national orchid industry has developed rapidly, especially in coastal cities, such as Guangdong, Fujian, Jiangsu, Zhejiang, Shanghai and other provinces, which have rich resources of national orchids.

\section{THE DEVELOPMENT ENVIRONMENT OF THE NATIONAL ORCHID CULTURE INDUSTRY}

The noble and pure cultural character of the national orchid endowed by Chinese traditional culture also made the literati adore it with spiritual love, thus forming the planting industry. The coastal Zhoushan of Zhejiang Province is a big city of national orchid. The national orchid of Zhoushan has a very important position in the nationwide orchid market. But the development of the national orchid culture industry in Zhoushan still has great obstacles as in other coastal cities. The author takes Zhoushan as an example to analyze the future development of the orchid culture industry.

\section{A. Large Price Fluctuation and Badly Damaged Resources}

Since ancient times, the national orchid has occupied an important position in the traditional culture as an image of elegance and pureness. In the past few years, the speculation of orchid has been prevailing, which makes the price of national orchid unreasonable. Outsiders are wantonly to dig up high-quality wild orchid, which damages the wild resources of the national orchid seriously. The high-quality national orchid resources in Zhoushan are also facing the crisis. Behind "carpet-typed" excavation, the wild national orchid resources are increasingly depleted in this crazy "plundering" development, and the national orchid resources of coastal Zhoushan are on the verge of depletion.

\section{B. Single Management Mode and Weak Comprehensive Utilization of Products}

The traditional national orchid management mode is limited only to the use of flower nursery planting and scattered sales. The cost is only invested in the preservation and cultivation of the existing flower seedlings, but neglecting innovation, ignoring the national orchid culture and marine economic added value, ignoring the benefits brought by the upgrading of the transport package to the national orchid economy, and gradually unable to adapt to the present national orchid market. The national orchid economy has entered the sluggish period.

\section{Lack of Brand Awareness and Leading Enterprises and Talents}

China's orchid planting area is the largest in the world. But so far, there has not been any famous brand. Although several Chinese orchid farming enterprises have a reputation, we still lack enterprises and talents that can lead the development of the entire national orchid culture industry.

\section{Unsound International Circulation Mechanism}

At present, we are faced with the decentralization of enterprises, low level of products, poor export channels, business being restricted to middlemen, backward marketing system, disjointed production and marketing, and weak international market development ability, and international competition has risen from price competition to price, quality, and service competition in all directions.

\section{THE DEVELOPMENT OF NATIONAL ORCHID CULTURE INDUSTRY BASED ON PEST ANALYSIS}

In recent years, Zhejiang has made rapid economic development, and people's quality of life has been greatly improved. There are more and more national orchid enthusiasts. As one of the typical representatives of the classical Zhejiang culture, orchid culture can help build a harmonious and civilized Zhejiang and expand and new space for innovative ocean economy. Therefore, Zhoushan, as a coastal city with deep orchid culture, has geographical and cultural advantages to promote the brands of Zhoushan orchid culture. Through market investigation and analysis, it is found that the sales industry of national orchid is not yet mature. Therefore, the analysis shows that Zhoushan has great potential in national orchid sales and brand promotion, wide market and strong feasibility. By using analysis of PEST, the author will analyze the situation faced by national orchid from the macro environment.

\section{A. Analysis of Political Factors}

Marketing is influenced and restricted by law and political environment at a large level. China has also issued a number of policies to the flower market, which is conducive to the growth of the flower market.

In Development Plan for National Flower Industry (2011 2020), the National Forestry Bureau clearly pointed out that the flower industry of our country is extending from the traditional flower planting industry to the flower processing industry and service industry. It is necessary to study and formulate the development planning of local flower industry with the combination of characteristics of local flower industry. We should actively strive for the supports from departments of development and reform, finance, science and technology, agriculture, quality inspection, customs, finance and other departments to create a favorable environment for the development of the flower industry. 
The period of $2011 \sim 2020$ is a critical period for China to build a well-off society in an all-round way, and also an important strategic opportunity time for promoting the scientific development of modern flower industry. The 18th National Congress of the Communist Party of China put forward to put the ecological civilization in a prominent position, and strive to build a beautiful China. It has pointed out the direction for the development of the flower industry, expanded the space and gave a new mission. It is suggested to take the development of the flower industry as an important duty of forestry work, strengthen, expand and fulfill the management functions of the flower industry, make great efforts to build up the capacity construction of institutions, teams and infrastructure, develop market early warning, and strengthen market regulation in order to create good conditions for the development of the flower industry [4].

On the basis of strict compliance with the law, we should recognize the overall situation of the society and make full use of the policy advantages. The construction and improvement of the ecological environment, the protection and utilization of the flower variety resources will lay a better foundation for the sustainable development of the national orchid industry and provide a broad prospect for the development of the national orchid industry.

\section{B. Analysis of Economic Factors}

With the development of flower industry, flower industry has become a major industry in global trade. The amount of flower consumption in the world has exceeded 200 billion US dollars by 2000 , and the average annual growth rate is close to $10 \%$. The consumption structure of indoor plants: fresh cut flowers account for $60 \%$, and small potted flowers account for $30 \%$. Among them, the proportion of national orchid is very large, which is an important part of flower industry. The annual turnover of the national orchid was more than 1 billion yuan, and more than 2000 varieties of national orchid were selected and cultivated. Global consumption of orchid grows at an annual rate of $10 \%$ to $20 \%$. The production and sales of cut orchids and potted orchids have been increasing continuously in recent years. The sale of potted orchid is second only to poinsettia in the US flower sales list. Sales continue to increase. It is estimated that the annual volume of potted orchids will exceed poinsettia in 2020 [5].

Orchids in China are rich in species and endemic, and the distribution is mainly concentrated in coastal areas. With the rapid development of the world economy and the expansion of the marine economy, the consumption of orchids has continued to grow rapidly. In China, we mainly plant national orchid, and there are about 500 thousand Orchid Growers in China and circulating fund of more than 1 billion yuan (RMB) in orchid market, including more than 20 million (USD) of orchid export trade income in "Fig. 1"[6].

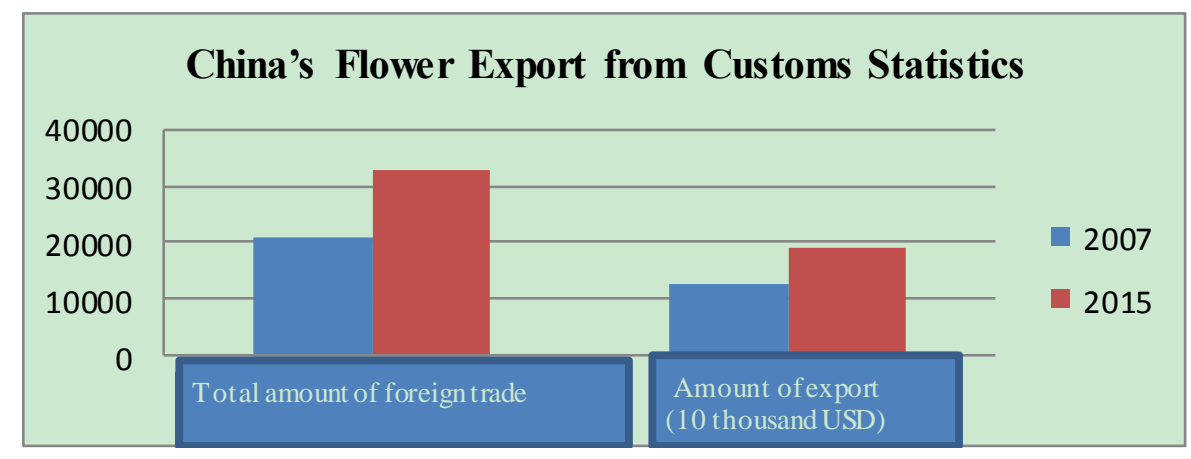

Fig. 1. China's flow export from customs statistics.

1) Consumer income level: The gross regional domestic product in 2017 (GDP) is 82.7122 trillion yuan, which is $6.9 \%$ higher than the previous year calculated according to comparable princes. Flowers are a kind of spiritual leisure and entertainment consumer goods. When people's material level reaches a certain height, they will seek spiritual enjoyment and begin to consume in large quantities. The level of consumer income determines their pursuit of flower consumption [6]. People with high income pay attention to self-cultivation and training a quiet and elegant mind by consuming orchid. General income people pay attention to role of orchid which can bring people peace, ease emotion and relive pressure. It gives an opportunity for the national orchid market "Fig. 2". 


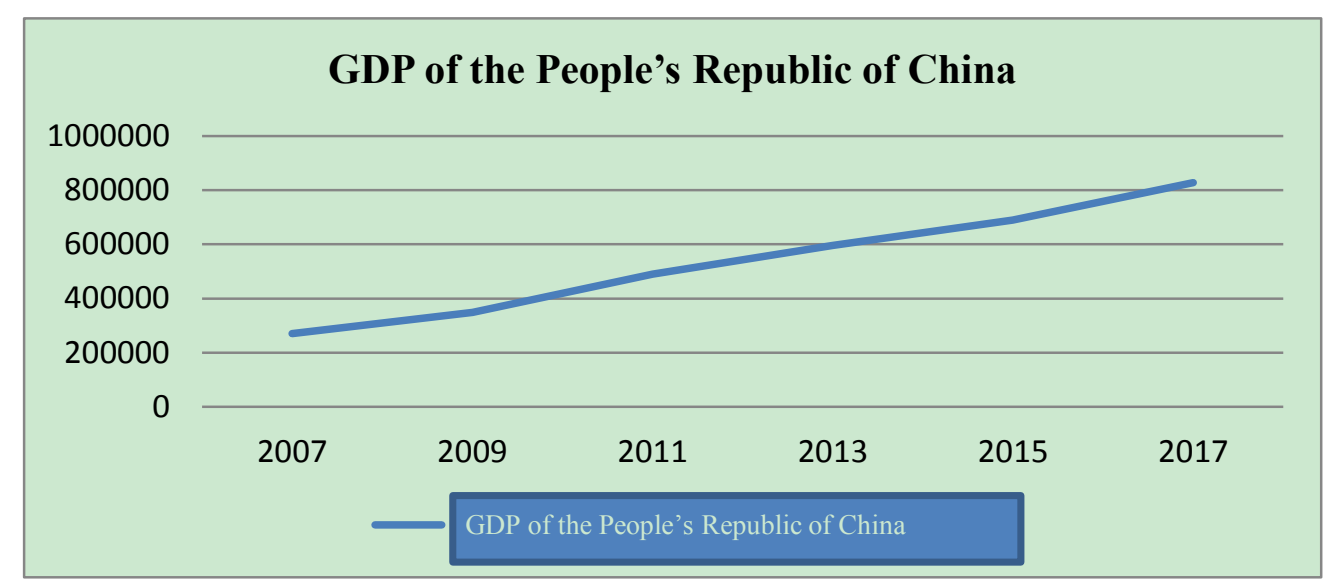

Fig. 2. GDP of the People's Republic of China.

2) Changes of consumer's consumption structure: With the improvement of living standards, the number of middle class, main flower consumers in China, is increasing rapidly, and the flower industry has great potential for development. The proportion of flower consumption during holidays is the largest. With the change of people's flower consumption habits, daily flower consumption gradually increases.

With the continuous and steady development of China's economy and the improvement of the people's quality of life, the national orchid has gradually become popular in life, such as interior decoration and gifts presenting. With the economic growth, people pay more and more attention to the quality of life. Presenting flowers, raising flowers and loving flowers have become a fashion.

3) Urbanization degree: The environmental factors of flower marketing also include urbanization. In 1980, China's urban population accounted for only $19 \%$ of the total population. By 2020, the government expects this figure will reach to $60 \%$. There are economic and cultural differences between urban and rural residents, and there are different flower consumption behaviors. Rural residents like growing flowers by themselves, while urban residents consume more potted flowers and buy more flowers during holidays than rural residents. But with the acceleration of China's urbanization process, many rural residents enter the city. The number of them buying flowers or planting potted flowers is also increasing.

\section{Analysis of Social-cultural Factors}

With the improvement of people's living level and the living environment of the people, the flowers' role in the improvement of the living environment is more obvious. Flowers are more and more used to decorate life. The increase of urban greening landscape has increased the market demand for flowers and driven the growth of flower industry.

Chinese people love orchid, not only because they love its beauty, but also it symbolizes gentleman in Chinese culture. Chinese people have deeper understanding and emotion on it. From generation to generation, Chinese people love orchid and appreciate orchid. We think orchid is pleasing to both eye and mind, and it can cultivate sentiment. Orchid contains our culture, and embodies character and temperance of China. In the view of Chinese, orchid is a spiritual thing. Apart from appreciating the static beauty of orchid, we also have interest in watching and appreciating the dynamic life change of orchid.

Culture has a lasting influence on people's consumption concept and consumption behavior. China has strong feelings for orchid. Therefore, the orchid industry is bound to have a huge consumer market in China.

\section{Analysis of Technological Factors}

The scale of the flower industry in China is expanding, the annual export amount of flowers is up to 200 million US dollars, and it has increased by the rate of more than $20 \%$. It has become a sunrise industry in China's export agricultural products [7]. For flower industry, technology development plays an important role in industry. In the past twenty years, flower science and technology play a vital role in the development of flower industry in China. We mainly introduce and absorb foreign famous flower varieties and advanced cultivation techniques. In the adjustment of rural industrial structure all over the country, flowers, as an effective way to raise farmers' income and strive for foreign exchange, have been nurtured and developed as a new industry, and the level of science and technology has been continuously improved. During the 11th Five-Year Plan, our capital faced opportunity to develop flower industry by building an international urban city.

In the past 30 years, the research education of flowers in China has developed rapidly. There are more than 100 national-level flower research units. More than 50 provincial-level agricultural and forestry universities, and technical secondary schools, vocational and technical colleges have set ornamental gardening or garden specialty, and continue to train and export urgently needed flower technology and management talents. The achievements in flower research are remarkable. Especially our ability of independent innovation has been greatly improved. The 
promotion and application of new varieties and new technologies have made obvious economic and social benefits [8].

At present, more than 300 varieties have been registered by the Chinese orchid variety logon committee. Remarkable progresses have been made in orchid physiology, resources and classification, cytology, rapid propagation technology of tissue culture, molecular biology, breeding technology, tube flowering, cultivation techniques and pest control and so on [3].

\section{STRATEGIES FOR THE DEVELOPMENT OF NATIONAL ORCHID CULTURE INDUSTRY}

\section{A. To Control the Price of the National Orchid and Protect the Cultural Resources}

At present, the national orchid has become urbanized and marketed. The prevailing trend of "orchid speculation" has led to excessive fluctuations in the price of national orchids. At this time, we need our governments to introduce relevant policies and control the market price of national orchids. In the face of the serious destruction of the wild resources, we should take protection measures to protect the high-quality orchid resources in the coastal Zhoushan immediately, set a special regional scope to protect our wild orchid resources. It is necessary to put forward a set of feasible and practical long-term protection mechanism and make research on the protection of cultural heritage.

\section{B. To Expand the Business Mode and Enhance the Comprehensive Utilization of Products}

The traditional orchid business mode should be expanded. We cannot only use the traditional way, but also use innovation to develop online and offline mode, make full use of "Internet +" orchid market to expand market, and upgrade transportation package, so as to improve the cultural and economic added value of orchid and the comprehensive utilization rate of products, ushering in the new era of the orchid economy.

\section{To Enhance Brand Awareness and Build the Brand of Zhoushan Orchid}

The planting area of orchid in China is the first in the world. But we still have no famous orchid brand. The coastal Zhoushan, as a city with a strong orchid culture and history, can build the brand of Zhoushan Orchid, promote the orchid brand consciousness with city to drive the development of entire orchid industry. We can strengthen the education and training of orchid planters in Zhoushan, organize professional technical and cultural forums for orchid planters, and raise their awareness on orchid. We can carry out mass cultural propaganda to form a benign social effect. We can combine Zhoushan orchid with coastal Zhejiang tourism, and make orchid become a new symbol of tourism in Zhoushan in the promotion and publicity process. We can hold orchid exhibitions and orchid festival to attract orchid lovers all over the country, improve reputation and expand influence.

\section{To Establish the System of National Orchid and Make Use of Ocean Trade}

We can sort out the veins of orchid and constructing vacancies in the orchid research system, and provide a solid theoretical foundation for the follow-up study of orchid culture. The government should play a leading role in the protection of cultural heritage, and strengthens management and investment on problems, such as unreasonable organizational structure and unsound maritime international circulation theory system. We can use the propaganda and promotion of the national orchid culture to carry out "Internet + " action plan, construct marine orchid trade and expand new space for marine economy.

\section{CONCLUSION}

Based on the PEST analysis, we can carry out the development strategy of the national orchid culture industry. Taking the New District of coastal Zhoushan Islands as an example, we can use political environment to provide a broad prospect for the development, and the expansion of the economic market environment, the increase of the number of consumers, the increasing demand of the market for the flowers, and the increasing technological environment to drive the development of the orchid industry.

We can build the cultural brand of the national orchid and dig the cultural communication value of our national orchid to make sales not only limited to the simple exchange of equivalence, help consumers explore the cultural value contained in it further, forming a far-reaching impact. We can go deep through the history and culture of orchid, and use traditional Chinese culture to position the gentleman image of orchid, so that orchid is distinguished from ordinary flowers because of the culture contained in it. We can take the culture brand of orchid as one of representatives of Zhoushan culture, and display them in large cultural exchange activities to promote its value and promote the protection awareness of people on orchid culture.

At the same time, the 13th Five-Year Plan proposed that we should cultivate new impetus and expand new space and expand the blue economic space. It is suggested to adhere to the overall planning of land and sea, strengthen the marine economy, develop marine resources scientifically, protect the marine ecological environment, safeguard China's marine rights and interests, and build a marine power. We can expand industrial development space, infrastructure construction space, and network economy space, implement "Internet + " action plan to develop the Internet of things technology and applications and sharing economy, and promote the integration of the Internet and economic and social development. Therefore, the upgrading project of national orchid economy came into being. We not only take national orchid as an economic industry, but also a cultural heritage, passing the orchid culture to every household. 


\section{REFERENCES}

[1] Yu Wengang. Research on Strategies for Orchid Resources and Industrialization Development in Hainan. Hainan: Hainan University, 2014.

[2] Lv Yuanlan. Home Grown Cymbidium, My Soul Mate. South Agriculture, 2009, 2: 1.

[3] China Forestry Bureau. Notice on printing and issuing Development Plan for National Flower Industry (2011 2020), 2013.

[4] Zhu Liuhua. Flower Industry in the Figure - Analysis of Statistics of Flower Industry in China from 1998 to 2001.Flower Horticulture in China, 2002, 14: 5-7.

[5] Li Zhenjian. Position and Development Trend of Cymbidium in the World Flower Trade. Chinese Agronomy Bulletin, 2008, 24 (5): 155.

[6] Huang Xin'ai. Marketing Strategy of Flower Industry in China. Hunan: Central South University of Forestry and Technology, 2006.

[7] Hu Yanchun. Cultivation and Export of Agricultural Flowers. Agricultural Economy, 2012, 6: 127-128.

[8] Jiang Zehui. Speech at the 20th Anniversary Commemoration Conference of the Flower Association of China. Flower Gardening in China, 2005, 5: 13-16. 